\title{
TIME VARYING CAUSALITY BETWEEN GOLD AND OIL PRICES
}

Gülfen TUNA*

\begin{abstract}
The causality relationship between gold and oil prices is analyzed in this research. For that purpose time-varying Hatemi-J (2012) Asymmetric Causality Analysis was used. Used data set was monthly gold and oil prices from May 2005 to March 2016. According to research results, the causality relationship from gold to oil is the concern in both positive and negative shocks and the periods of important economic, social or political events. However, the causality relationship from oil to gold is only valid for positive shocks, but it is not valid for negative shocks.
\end{abstract}

Key Words: Gold Prices, Oil Prices, Asymmetric Causality, Positive Shocks, Negative Shocks.

JEL Codes: C58, G11, Q43.

\section{Introduction}

Gold is one the precious metals used as a safe investment tool with high trading volume in financial markets. However, oil is one the raw materials with high trading volume as gold. Precious metals such as gold and oil are significant components affecting the financial markets. So both economic variables of them and the fact of affecting each prices are the interest of theoreticians and practitioners. Because these data are very important for the investors in order to develop a suitable portfolio management strategy through effective diversification and provide profit maximization by making price predictions with low estimation errors. Therefore, the studies analyzing whether precious metals affect the prices of each other form one of the significant issues of economic researches. Melvin and Sultan (1990) are one the first researchers analyzing the relationship between gold and oil prices. Melvin and Sultan (1990) remark that oil exporting countries have substantial gold reserve in their international portfolio investments. They state that these countries increase the share of gold in their total portfolio with the increase in world oil prices.

A general view is dominant in financial markets accepting that "gold prices follow oil prices". Many studies in current literature also support that the changes in oil prices cause changes in gold prices (Sari et al 2010). It is also stated in Soytaş et al(2009)'s study that there is an asymmetric and weak relationship between gold revenues and oil revenues. According to Sari et al (2010)'s research results that they analyzed the effect of oil price shocks on precious metal revenues and US dollar/ EURO Exchange rate, precious metal market gives a positive and statistically significant reaction to the changes in oil prices.

*Gülfen TUNA is Associate Prof. of Finance at the Sakarya University, Turkey. E-mail: geksi@sakarya.edu.tr 
However, according to Baffes (2007)'s research result that he analyzed the relationship between brent oil prices and the price changes of 35 goods trading in international markets, gold, one of the precious metals, gives the strongest reaction against the oil price changes. There are different approaches which try to explain this relationship between gold and oil prices in current literature. According to the first approach, the relationship between gold and oil prices is tried to be explained with inflation. According to this approach, the increase in oil prices affects general level of prices (Hunt, 2006). In such a case the investors who would like to prevent from inflation prefer gold as a safe investment tool. As a result of this fact it is stated that gold prices will increase (Jaffe, 1989). It is stated in Narayan at all (2010)'s research results in which he analyzed the long term relationship between gold and oil prices in both spot and futures markets that gold is effectively used by all investors in order to prevent from inflation. Also it is stated that gold and oil prices will be used in price estimation for each other. According to the first approach explaining the relationship between gold and oil prices through inflation, this situation supports that these two metals move in the same direction. However, according to the second approach, the energy used for extracting and processing gold is a significant cost element. Oil and its derivatives are the energy resources used commonly in products. Therefore, as we think that oil is an energy resource, high oil prices may cause high energy costs and also high gold prices. According to the third approach, high oil prices affect the economic growth negatively. This negative influence of economic growth reduces stock prices. Investors tend to gold from alternative investment tools in order to reduce the risk that they have due to their investments in stock exchange markets (Reboredo, 2010). Also the demand to gold used commonly in financial markets as a safe investment tool causes this the price of precious metal to increase. Reboredo (2013) in his study analyzed whether gold is a protection from risk or a safe investment tool against oil price movements. In practice results with weekly data set in 2000-2011 periods it is stated that gold is not a protection tool against oil price movements.

Financial markets are affected from oil and gold price changes directly or indirectly. Therefore, not only knowing the long term relationship between precious metals but also knowing which metal is effective on which price change of the metal is also important for an effective portfolio diversification. There are different studies analyzing this situation in current literature. From these studies Soytaş et al. (2009) analyzed the long and short term relationship between world oil, gold silver Turkish Lira/Dollars foreign exchange rate and Turkish Bond Rate. In research results it is stated that world oil prices do not affect the gold prices in Turkey. However, Zhang and Wei (2010) analyzed the cointegration and causality relationship between brent oil and gold market prices for 2000-20008 period. According to research results there is a coherent trend between gold and oil prices and correlation coefficient about this relationship in analyzed period is positive and statistically significant. Lee et al. (2012) also analyzed the long term relationship between gold and oil prices. According to the reseach results, there is a long term relationship between oil and gold prices and there is a one-way causality relationship from oil prices to gold prices. Tiwari and Sahadudheen (2015) analyzed the relationship between gold and oil prices in 1990-2013 periods through GARCH models. According to the research results, positive and negative shocks in oil prices have different effects on gold prices in terms of size. 
Also in this study the causality relationship between oil prices and gold prices is analyzed. Whether these two precious metals stably provide the useful data for each other or not is also analyzed in price estimation of them. For that purpose, time-varying asymmetric causality relationship is used to identify the causality relationship. The most important reason why asymmetric causality analysis is preferred is the different reactions of investors to positive and negative shocks. Through this analysis the effect of positive and negative shocks in both gold and oil prices can be analyzed separately. At the same time whether the concerned relationships are stable or not is analyzed with the practice of its time-varying form. In accordance with these targets, the most important contribution of this study to literature is to identify whether there is stable causality relationship or not by decomposing the change in gold and oil prices to positive and negative shocks. So whether positive and negative values in gold prices provides useful data in the generation of positive and negative values in oil prices is analyzed. This relationship is also analyzed from oil prices to gold prices. Therefore, the overall view that "gold prices follow the oil prices" can be analyzed for the positive and negative shocks. Accordingly, this study consists of five parts. In introduction part the related literature and general information, in the second part methodology and in the third part data set are included. In the fourth part the obtained findings are included and in last part an overall evaluation is made according to the obtained findings.

\section{Econometric Metodology}

In order to analyze the causality relationship between oil and gold prices, initially whether the series are stable or not is analyzed. Fort his analysis Carrion-i Silvestre unit root test was used in the research. Carrion-i Silvestre (2009) allows for five structural fractions at most. Also, this test intrinsically determines fractions points. The test obtains fractions points by using Bai and Perron (2003) algorithm and with the help of QuasiGLS (Generalized Least Squares), dynamic program process and minimizing total of fault remnants. In this test technique, effective results can be obtained with small sampling (Carrion-i Silvestre, 2009). Stochastic data production process used in the test is in the following:

$$
\begin{aligned}
& y_{t}=d_{t}+u_{t} \\
& u_{t}=a u_{t-1}+v_{t}, \quad t=0, \ldots \ldots \ldots \ldots \ldots \ldots \ldots T
\end{aligned}
$$

Carrion-i Silvestre (2009) developed five different test statistics to test stable nature of the sets:

$$
\begin{gathered}
\mathrm{P}_{\mathrm{T}}\left(\lambda^{0}\right)=\left\{\mathrm{S}\left(\bar{\alpha}, \lambda^{0}\right)-\bar{\alpha} \mathrm{S}\left(1, \lambda^{0}\right)\right\} / \mathrm{s}^{2}\left(\lambda^{0}\right) \\
\mathrm{MP}_{\mathrm{T}}\left(\lambda^{0}\right)=\left[\mathrm{c}^{-2} \mathrm{~T}^{-2} \sum_{\mathrm{t}=1}^{\mathrm{T}} \tilde{\mathrm{y}}_{\mathrm{t}-1}^{2}+(1-\tilde{\mathrm{c}}) \mathrm{T}^{-1} \tilde{\mathrm{y}}_{\mathrm{T}}^{2}\right] / \mathrm{s}\left(\lambda^{0}\right)^{2}(4) \\
\mathrm{MZ}_{\alpha}\left(\lambda^{0}\right)=\left(\mathrm{T}^{-1} \tilde{\mathrm{y}}_{\mathrm{T}}^{2}-\mathrm{s}\left(\lambda^{0}\right)^{2}\right)\left(2 \mathrm{~T}^{-2} \sum_{\mathrm{t}=1}^{\mathrm{T}} \tilde{\mathrm{y}}_{\mathrm{t}-1}^{2}\right)
\end{gathered}
$$




$$
\begin{gathered}
\operatorname{MSB}\left(\lambda^{0}\right)=\left(s\left(\lambda^{0}\right)^{-2} \mathrm{~T}^{-2} \sum_{\mathrm{t}=1}^{\mathrm{T}} \tilde{\mathrm{y}}_{\mathrm{t}-1}^{2}\right)^{-\frac{1}{2}}(6) \\
\operatorname{MZ}_{\mathrm{t}}\left(\lambda^{0}\right)=\left(\mathrm{T}^{-1} \tilde{\mathrm{y}}_{\mathrm{T}}^{2}-\mathrm{s}\left(\lambda^{0}\right)^{2}\right)\left(4 \mathrm{~s}\left(\lambda^{0}\right)^{2} \mathrm{~T}^{-2} \sum_{\mathrm{t}=1}^{\mathrm{T}} \tilde{\mathrm{y}}_{\mathrm{t}-1}^{2}\right)^{-\frac{1}{2}}
\end{gathered}
$$

Hypotheses of the test:

$\mathrm{H}_{0}$ : There is a unit root under structural fractions.

$\mathrm{H}_{1}$ : There isn't unit root under structural fractions.

Asymptotic values necessary for testing these hypotheses are produced by bootstrap. When the calculated test statistic is less than the critical value, $\mathrm{H}_{\mathrm{O}}$ hypothesis is rejected. When there is a structural fraction in the set, it is found that the new set is stable and there isn't any unit root (Göçer and Peker, 2014).

Main purpose of this research is to identify whether there is a stable causality relationship between gold and oil prices. For that purpose, after the unit root test Hatemi-J (2012) Asymmetric causality test was applied as time-varying.

However, Hatemi-J (2012) developed Granger and Yoon (2002) approach for the causality test. In this asymmetric causality test it is aimed to find the hidden structures to help understand the structure of the analyzed series and enable to make estimations for the future. Accordingly, suppose that the causality relationship between two integrated series such as $\mathrm{y}_{1 t}$ and $\mathrm{y}_{2 \mathrm{t}}$ is tested:

$$
\begin{aligned}
& y_{1 t}=y_{1 t-1}+\varepsilon_{1 t}=y_{1,0}+\sum_{i=1}^{t} \varepsilon_{1 i} \\
& y_{2 t}=y_{2 t-1}+\varepsilon_{2 t}=y_{2,0}+\sum_{i=1}^{t} \varepsilon_{2 i}
\end{aligned}
$$

Here $\mathrm{y}_{1,0}$ and $\mathrm{y}_{2,0}$ indicate the initial values. Positive and negative shocks can be indicated as the following:

$$
\begin{aligned}
& \varepsilon_{1 i}^{+}=\operatorname{maks}\left(\varepsilon_{1 i}, 0\right), \quad \varepsilon_{1 i}^{-}=\min \left(\varepsilon_{1 i}, 0\right) \\
& \varepsilon_{2 i}^{+}=\operatorname{maks}\left(\varepsilon_{2 i}, 0\right), \quad \varepsilon_{2 i}^{-}=\min \left(\varepsilon_{2 i}, 0\right) \\
& \varepsilon_{1 i}=\varepsilon_{1 i}^{+}+\varepsilon_{1 i}^{-} \\
& \varepsilon_{2 i}=\varepsilon_{2 i}^{+}+\varepsilon_{2 i}^{-}
\end{aligned}
$$

can be stated as. 
According to this data it is possible to indicate the numbered (1) and (2) equalities again as the following by editing.

$$
\begin{aligned}
& y_{1 t}=y_{1 t-1}+\varepsilon_{1 t}=y_{1,0}+\sum_{i=1}^{t} \varepsilon_{1 i}^{+}+\sum_{i=1}^{t} \varepsilon_{1 i}^{-} \\
& y_{2 t}=y_{2 t-1}+\varepsilon_{2 t}=y_{2,0}+\sum_{i=1}^{t} \varepsilon_{2 i}^{+}+\sum_{i=1}^{t} \varepsilon_{2 i}^{-}
\end{aligned}
$$

However, the positive and negative shocks in each variable are stated as the following in accumulated form:

$$
\begin{gathered}
y_{1 i}^{+}=\sum_{i=1}^{t} \varepsilon_{1 i}^{+}, \quad y_{1 i}^{-}=\sum_{i=1}^{t} \varepsilon_{1 i}^{-}, \\
y_{2 i}^{+}=\sum_{i=1}^{t} \varepsilon_{2 i}^{+}, \quad y_{2 i}^{-}=\sum_{i=1}^{t} \varepsilon_{2 i}^{-}
\end{gathered}
$$

In time varying asymmetrical causality test, firstly Hatemi (2012) causality test is applied for the space between $1^{\text {st }}$ and $20^{\text {th }}$ observations. At the second step, the first observation is disregarded, and this test is applied to $(20+1)$ observation range with second observation; and at every new step of the test, the first observation is disregarded and continued till the last observation existing in data range, by adding a new observation to the last one at each step. The values are shown in a graph in order to comment obtained Wald test statistics. In the graph, the values above " 1 " line shows the necessity of rejecting the main hypothesis that shows there is not asymmetric Granger causality (Y1lanci and Bozoklu, 2014).

\section{Data}

The time-varying causality relationship between oil and gold prices was analyzed with monthly data set for the periods from 2005 May and 2016 March. For gold prices London Fix Prices obtained from www.kitco.com and for oil prices Europe Brent Spot Price FOB (Dollars per Barrel) obtained from www.eia.gov.tr were used in the research. All analyses were made after natural logarithms of all data used in the research were taken.

\section{Results}

\subsection{Results of Carrion-i Silvestre Unit Root Test}

Carrion-i Silvestre which allows five structural breaks unit root test was applied to the gold and oil prices whose natural logartihms were taken. The obtained findings are as in Table 1. 
Table 1. Results of Carrion-i Silvestre Unit Root Test

\begin{tabular}{|c|c|c|c|c|c|}
\hline \multicolumn{6}{|c|}{ OIL } \\
\hline & \multicolumn{2}{|l|}{ Level } & \multicolumn{3}{|c|}{ First Difference } \\
\hline & $\begin{array}{l}\text { Test } \\
\text { Statistics }\end{array}$ & $\begin{array}{l}\text { Critical } \\
\text { Values }\end{array}$ & $\begin{array}{l}\text { Break } \\
\text { Dates }\end{array}$ & $\begin{array}{l}\text { Test } \\
\text { Statistics }\end{array}$ & $\begin{array}{l}\text { Critical } \\
\text { Values }\end{array}$ \\
\hline $\mathrm{P}_{\mathrm{T}}$ & 18,731 & 8,496 & July 2006 & $3,307 *$ & 5,418 \\
\hline $\mathrm{MP}_{\mathrm{T}}$ & 16,571 & 8,496 & Sep. 2008 & $3,106^{*}$ & 5,418 \\
\hline $\mathrm{MZ}_{\alpha}$ & $-23,662$ & $-45,021$ & Apr. 2009 & $-46,883^{*}$ & $-25,755$ \\
\hline MSB & 0,144 & 0,104 & Dec.2010 & $0,103^{*}$ & 0,142 \\
\hline $\mathrm{MZ}_{\mathrm{T}}$ & $-3,418$ & $-4,746$ & \begin{tabular}{|l|} 
Jun. 2014 \\
\end{tabular} & $-4,840 *$ & $-3,602$ \\
\hline \multicolumn{6}{|c|}{ GOLD } \\
\hline & \multicolumn{2}{|l|}{ Level } & \multicolumn{3}{|c|}{ First Difference } \\
\hline & $\begin{array}{l}\text { Test } \\
\text { Statistics }\end{array}$ & $\begin{array}{l}\text { Critical } \\
\text { Values }\end{array}$ & $\begin{array}{l}\text { Break } \\
\text { Dates }\end{array}$ & $\begin{array}{l}\text { Test } \\
\text { Statistics }\end{array}$ & $\begin{array}{l}\text { Critical } \\
\text { Values }\end{array}$ \\
\hline $\mathrm{P}_{\mathrm{T}}$ & 12,085 & 9,274 & May. 2006 & 10,385 & 9,282 \\
\hline $\mathrm{MP}_{\mathrm{T}}$ & 10,751 & 9,274 & Jun. 2007 & $9,268^{*}$ & 9,282 \\
\hline $\mathrm{MZ}_{\alpha}$ & $-43,011$ & $-46,753$ & \begin{tabular}{|l|} 
July. 2008 \\
\end{tabular} & $-47,164 *$ & $-46,734$ \\
\hline MSB & 0,106 & 0,103 & \begin{tabular}{|l|} 
Aug. 2011 \\
\end{tabular} & $0,102 *$ & 0,103 \\
\hline $\mathrm{MZ}_{\mathrm{T}}$ & $-4,564$ & $-4,809$ & Mar. 2013 & $-4,854 *$ & $-4,811$ \\
\hline
\end{tabular}

Note: ${ }^{*}$ indicates the stability at $5 \%$ of significance level. The values in parenthesis are the critical values generated by using bootstrap with 1000 repetition. Dates of structural breaks are the dates determined by the test method.

According to CS unit root test results, structural breaks occurred in 2006, 2008, 2009, 2010 and 2014 for oil prices and in 2006, 2007, 2008, 2011 and 2013 for gold prices. According to the unit root test results conducted with level values of oil and gold prices whose natural logarithms were taken, the obtained test statistics are higher than the critical values. This indicates that both gold and oil prices are not stable for level values. According to the unit root test results by taking the first differences of each two series, series are stable.

We continue to apply Hatemi-J (2012) time-varying asymmetric causality test with the series which became stable by taking their first differences. The results according to Hatemi-J time-varying asymmetric causality test are presented in Figure1.

\subsection{Results of Time-Varying Asymmetric Causality Test}

In Figure 1 there is a causality relationship from gold to oil for positive shocks.

Figure 1. From Gold to Oil for Positive Shocks

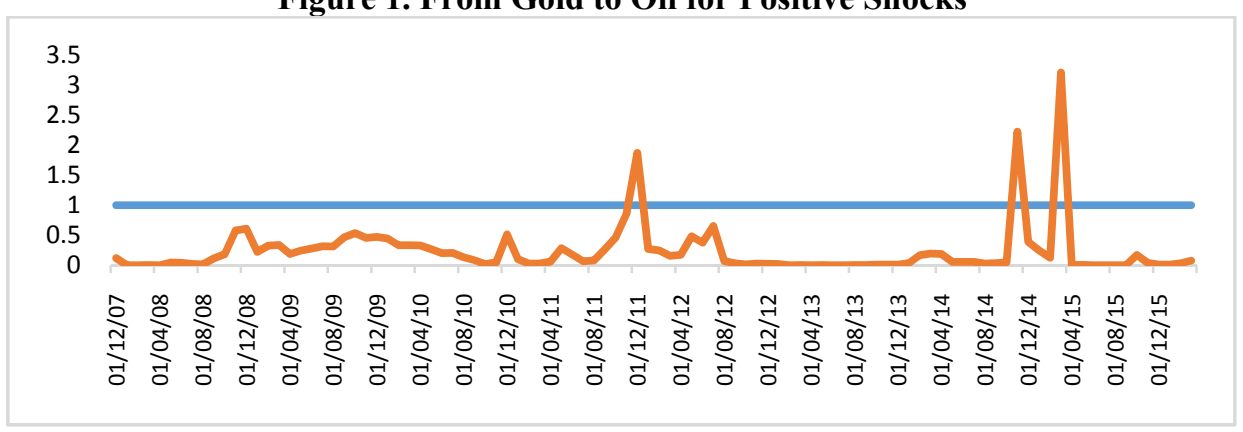


As can be seen in Figure 1, the causality relationship from gold prices to oil prices in positive shocks emerges obviously in December 2011, November 2014 and March 2014 periods. There is no causality from gold prices to oil prices in other periods. In 2011 when the first causality relationship was observed gold prices increased at record high. Also the effects of economic crisis affecting USA and Europe coincide with this period again. In December 2014 and March 2015 periods again one of the economic events that could be the source of the causality relationship from gold prices to oil prices may be Russia's cancellation of South Stream Project that Russia would provide natural gas to Europe.

Figure 2. From Gold To Oil For Negative Shocks

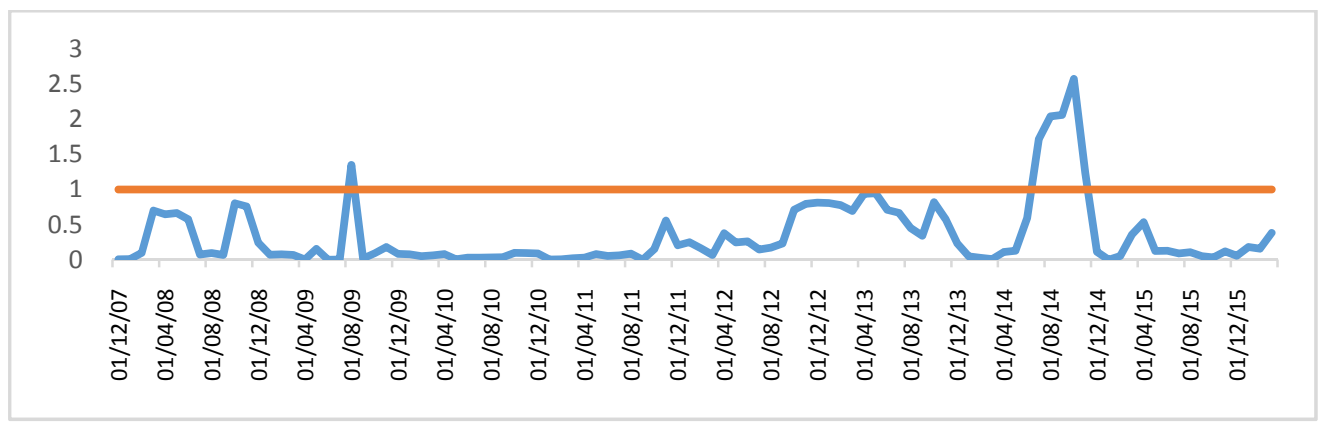

However, according to Figure 2, there is causality relationship from gold prices to oil prices for negative shocks in especially last period of 2009 and 2014. When the events happened in this period are analyzed in detail, cancelation of South Stream Project draws attention. This project was cancelled since Russia and Bulgaria could not come to an agreement. Also in this period the agreements about nuclear energy and oil searching between India and Russia are the important events affecting gold and oil prices.

Figure 3. From OilTo Gold For Pozitive Shocks

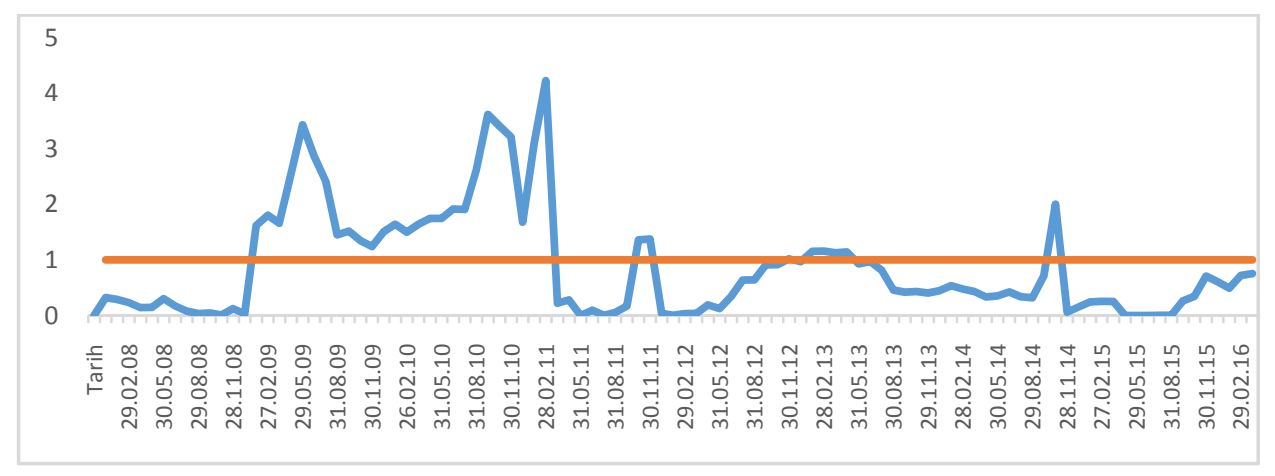

According to Figure 3 there is a stable causality relationship from oil prices to gold prices between 2009 and 2011 for the positive shocks. When this period is analyzed, the mortgage crisis in 2008 and then the economic crisis affecting both USA and Europe in 2011 draw attention. Also cancelation of South Stream Project occurred at the end of 2014 and the agreements between Russia and India in energy sector can be indicated as the source of causality relationship happened in this period. 
Figure 4. From Oil To Gold For Negative Shocks

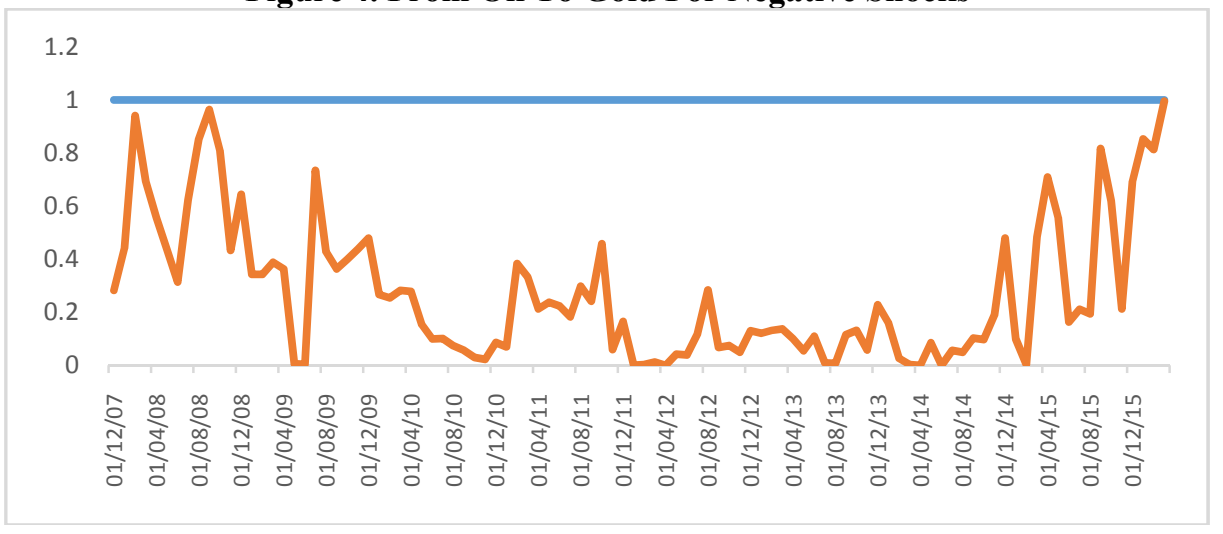

When Figure 4 is analyzed, there is no causality relationship from oil prices to gold prices for the negative shocks for any periods. This supports the general attitude that "gold prices follow oil prices" is not valid for negative shocks.

\section{Conclusion}

In this study the causality relationship between gold prices and oil prices was analyzed. Monthly data including 2005-2016 period were used in this study. Causality analysis was studied through time-varying Hatemi-J (2012) Asymmetric Causality Analysis. Through this analysis the effects of positive and negative shocks in both gold and oil prices were analyzed separately. Moreover, this study is also very important for determining whether the causality relationship between gold and oil prices is stable or not according to the applied analysis results.

According to the obtained results, there is a causality relationship from gold prices to oil prices in both positive and negative shocks. However, this relationship is not stable and it happens depending on the mortgage crisis in 2008, the economic crisis in 2011 or the strategic partnerships and cooperation's of strong economies in the world in 2014. The reaction to important economic events and the events related to energy sector in negative shocks is higher and faster than positive shocks. Accordingly, gold prices in economic crisis and energy agreements stand for as a significant variable to estimate oil prices. This is higher and stronger in negative shocks. The fact that oil prices provide useful data in the estimation of gold prices is only valid for positive shocks but it is not valid for negative shocks. In other words, while oil prices provide useful data in the estimation of gold prices in positive shocks, this is not valid for negative shocks. The findings obtained as a result of this study are similar to Melvin and Sultan (1990), Baffes (2007), Soytaş (2009), Zhang and Wei (2010)'s studies. However, although it has partly simiar results with Narayan (2010) and Lee at al.(2012), it has important differences.

In this research the general attitude that "gold prices follow oil prices" is highly rejected. Because the obtained findings support that this is only valid for positive shocks in important economic events and possible agreements or the agreements in energy sector. There is no causality relationship in any period of time for the analyzed periods in 
$\overline{\text { negative shocks. However, oil prices follow gold prices in important economic events and }}$ in the issues about energy sector in both positive and negative shocks.

In studies in the future more comprehensive studies can be carried out by associating oil prices with different macroeconomic variables such as national gold prices, foreign exchange rate, stock exchange index.

\section{References}

Baffes, J. (2007). Oil Spills on Other Commodities. Resources Policy, 32(3), 126-134.

Bai, J., and Perron, P. (2003). Computation and Analysis of Multiple Structural Change Models. Journal of Applied Econometrics, 18(1), pp.1-22.

Carrıon-1-Silvestre, Lluís, J. Kım D. and Perron P. (2009). GLS-Based Unit Root Tests with Multiple Structural Breaks Under Both the Null and the Alternative Hypotheses. Econometric Theory, 25, pp.1754-1792.

Göçer, İ. ve Peker, O. (2014). Yabancı Doğrudan Yatırımların İstihdam Üzerindeki Etkisi: Türkiye, Çin ve Hindistan Örneğinde Çoklu Yapısal Kırılmalı Eşbütünleşme Analizi. Yönetim ve Ekonomi, Cilt:21, Say1:1, ss.107-123.

Granger, C. W., and G. Yoon (2002), 'Hidden Cointegration', Department of Economics Working Paper, University of California, San Diego.

Hatemi-J, A. (2012), Asymmetric Causality Tests with an Application. Empirical Economics, 43(1): 447-456.

Hunt, B. (2006). Oil Price Shocks And the US Stagflation of the 1970s: Some Insights from GEM. The Energy Journal, 61-80.

Jaffe, J., F. (1989), Gold and Gold Stocks as Investments for Institutional Portfolios. Financial Analysts Journal, March-April, 1989, 4,2, 53-59.

Lee, Y. H., Huang, Y. L., \& Yang, H. J. (2012). The Asymmetric Long-Run Relationship Between Crude Oil And Gold Futures. Global Journal of Business Research, 6(1), 9-15.

Melvin, M., \& Sultan, J. (1990). South African Political Unrest, Oil Prices, And The Time Varying Risk Premium In The Gold Futures Market. Journal of Futures Markets, 10(2), 103-111.

Narayan, P. K., Narayan, S., \& Zheng, X. (2010). Gold and Oil Futures Markets: Are Markets Efficient?. Applied Energy, 87(10), 3299-3303.

Reboredo, J. C. (2010). Nonlinear Effects of Oil Shocks On Stock Returns: a Markovswitching approach. Applied Economics, 42(29), 3735-3744.

Reboredo, J. C. (2013). Is Gold a Safe Haven or a Hedge for the US Dollar? Implications for Risk Management. Journal of Banking \& Finance, 37(8), 2665-2676.

Sari, R., Hammoudeh, S., \& Soytas, U. (2010). Dynamics of Oil Price, Precious Metal Prices, And Exchange Rate. Energy Economics, 32(2), 351-362.

Soytas, U., Sari, R., Hammoudeh, S., \& Hacihasanoglu, E. (2009). World Oil Prices, Precious Metal Prices And Macroeconomy in Turkey. Energy Policy,37(12), 5557-5566.

Tiwari, A. K., \& Sahadudheen, I. (2015). Understanding The Nexus Between Oil And Gold. Resources Policy, 46, 85-91.

Yılancı, V. and Bozoklu, Ş.(2014), Türk Sermaye Piyasasında Fiyat ve İşlem Hacmi İlişkisi: Zamanla Değişen Asimetrik Nedensellik Analizi, Ege Academic Review, 14(2): 211-220.

Zhang, Y. J., \& Wei, Y. M. (2010). The Crude Oil Market and the Gold Market: Evidence for Cointegration, Causality And Price Discovery. Resources Policy,35(3), 168-177. 